TTR

Traduction, terminologie, re?daction

\title{
Translation as Culture Transfer: Evidence from African Creative Writing
}

\section{Paul F. Bandia}

Volume 6, numéro 2, 2e semestre 1993

Traduction, mixité, politique

URI : https://id.erudit.org/iderudit/037151ar

DOI : https://doi.org/10.7202/037151ar

Aller au sommaire du numéro

Éditeur(s)

Association canadienne de traductologie

ISSN

0835-8443 (imprimé)

1708-2188 (numérique)

Découvrir la revue

\section{Citer cet article}

Bandia, P. F. (1993). Translation as Culture Transfer: Evidence from African Creative Writing. TTR, 6(2), 55-78. https://doi.org/10.7202/037151ar

\section{Résumé de l'article}

Traduction et transfert culturel : le cas de la création littéraire africaine - La tradition orale africaine exerce une influence marquée sur le langage de la création littéraire africaine en langues européennes (le français et l'anglais) qui pose des problèmes de traduction particuliers. La présente étude décrit les diverses techniques et les divers procédés de traduction utilisés par les traducteurs d'oeuvres africaines écrites en langues européennes. La discussion de ces procédés conduit à aborder des concepts bien connus dans le domaine de la traductologie : la traduction sémantique et la traduction communicative de Newmark, la \#x00ab; overt translation " et la " covert translation » de House, la traduction primaire et la traduction secondaire de Diller et Kornelius et enfin la traduction ethnocentrique et la traduction hypertextuelle de Berman. La traduction comme transfert culturel, particulièrement en ce qui concerne des langues de cultures très éloignées l'une de l'autre, a été abordée entre autres par des théoriciens tels que Mounin, Nida et Snell-Hornby. La traduction d'oeuvres africaines est une " double transposition » : (1) l'auteur exprime la "pensée » africaine en langue européenne; (2) le traducteur effectue un " transfert » de la pensée africaine d'une langue européenne à une autre. La variété africaine de la langue européenne constitue un défi pour le traducteur, qui doit surmonter les problèmes particuliers que pose la traduction d'une telle variété « non standard » de langue européenne. Une analyse des divers procédés utilisés par les traducteurs d'oeuvres africaines en langues européennes révèle une préférence marquée pour une traduction plutôt sémantique, transparente (" overt ") et littérale, dans laquelle, pour emprunter à E. Nida, Y équivalence formelle l'emporterait sur l'équivalence dynamique. Cette approche est la plus apte, selon les traducteurs, à assurer une représentation efficace des réalités sociolinguistiques et socioculturelles africaines en langues européennes.
Tous droits réservés (C) TTR: traduction, terminologie, rédaction — Les auteurs, 1993
Ce document est protégé par la loi sur le droit d'auteur. L’utilisation des services d'Érudit (y compris la reproduction) est assujettie à sa politique d'utilisation que vous pouvez consulter en ligne.

https://apropos.erudit.org/fr/usagers/politique-dutilisation/ 


\title{
Translation as Culture Transfer: Evidence from African Creative Writing
}

\author{
Paul F. Bandia
}

\section{Introduction}

It is generally agreed that African creative writing in European languages has been greatly influenced by African oral tradition (Obiechina, 1975; Chinweizu et al., 1980; Gérard, 1986; Bandia, 1993). This influence has given rise to a variety of the European languages of writing (French and English) that can safely be considered African. The nature of these Africanized varieties poses specific problems for translators of African works. We wish to illustrate the various processes and techniques used to cope with these difficulties.

Translation is an intercultural activity as well as an intralingual one as it deals with (at least) two linguistic systems embedded in two different cultures ${ }^{1}$. However, the difficulties inherent in the translation process vary proportionately with the degree of distance between the languages and the cultures involved. Translation of African works into European languages

1. Our definition of culture is similar to Snell-Hornby's, when she points out that culture is not understood here "in the narrow sense of man's advanced intellectual development as reflected in the arts, but in the broader anthropological sense to refer to all socially conditioned aspects of human life [...]" (1988, p. 39). 
is an example of a translation between non-related languages and cultures. It is a translation of an oral "text" into written form, on the one hand, and a translation from one language culture into an alien language culture, on the other. It has been pointed out by Snell-Hornby (1988, p. 41), among others, that "the extent to which a text is translatable varies with the degree to which it is embedded in its own specific culture, also with the distance that separates the cultural background of source text and target audience in terms of time and place."

\section{Choosing a translation approach}

Contemporary approaches to the study of language have provided us with tools with which to study the process of translating from an orally-based language-culture into a Western language-culture, and to assess the impact that such translations may have in the receptor Western language-culture.

Contact between two alien cultures amounts to a confrontation between two heterogenous sensibilities that are deeply rooted in the intrinsic value systems of their respective cultures.

Cultural value systems are difficult to grasp as they are intricately woven into the texture of the native language. A conscientious translator ${ }^{2}$, therefore, must be willing to make the extra effort that is required to unearth the full cultural meaning hidden in the language. He must be alive to the two sociocultural systems with which he is working in order to narrow the gap that separates them. His task becomes even more complicated when he is working between two languages of divergent sociocultural backgrounds and the issue takes another twist when the translation is between the languages of the "colonizer" and the "colonized." The translator must then be particularly careful about how he handles the material of the source language in his desire to be faithful to the target language and culture. Although

2. The term is used here to mean an African author writing in a European language or a translator of African works. 
this is true of any translation, what sets it apart is the fact that the translator should strive to avoid exacerbating tensions created by past historical events (colonialism), by ensuring that no "negative stereotyping" due to ignorance of the source culture occurs in the translation. An unbalanced approach might ultimately undermine the quality of the translated material. In a nutshell, while being aware of the sensibilities of the target language reader, the translator should also endeavour to preserve the sociocultural content of the source language.

\section{A Source-Text Oriented Translation}

\section{A. Prospective versus retrospective translation}

The most recent approaches to translation, according to SnellHornby, are an "orientation towards cultural rather than linguistic transfer, [a view of] translation, not as a process of transcoding, but as an act of communication, [an orientation] towards the function of the target text (prospective translation) rather than prescriptions of the source text (retrospective translation) [and a view of] the text as an integral part of the world and not an isolated specimen of language" (Snell-Hornby, 1988, pp. 43-44). These new perspectives can throw some light on the difficulty of translating African oral literature. As Snell-Hornby continues in her description of these approaches, she points out that:

The text is embedded in a given situation, which is itself conditioned by its sociocultural background. The translation is then dependent on its function as a text "implanted" in the target culture, whereby there is the alternative of either preserving the original function of the source text in its culture [...] or of changing the function to adapt to specified needs in the target culture [our italics]. (1988, p. 44)

This is the dilemma facing the translator of African works who, for the most part, has elected to "preserve the original function of the source text in its culture." Thus, while Snell-Hornby places emphasis on situation of source text and function of the translation (1988, p. 112), the translator of African works is mainly concerned 
with preserving the "situation of the source text." The translation process involved here defies the traditional approach which views translation as a mere substitution of linguistic and cultural equivalents. It is certainly not in unison with the view of Bible translators (Nida, Taber, among others) and other proponents of ethnocentric translation, who endorse a form of translation practice that quite often results in the re-creation of a piece of art into something far removed from the reality of the culture of the source language. It is a translation process which, in House's (1977) terms, is overt and not covert; it is a primary and not a secondary exercise (Diller and Kornelius, 1978), semantic and not communicative (Newmark, 1981). It is not literal translation per se, but translation written at the level of the source-text culture, in order to ensure that both the translator and the reader are receiving the message at the level of the source-text culture. Hence, it is not a free translation, and consequently hardly any effort is made to "filter" or adapt the source text to the reader's culture and knowledge. In short, it is a source-text-oriented translation and not an ethnocentric translation. ${ }^{4}$

\section{B. "Traduction hypertextuelle" and "traduction ethnocentrique"}

Antoine Berman (1985) defines ethnocentric translation as "[la traduction] qui ramène tout à sa propre culture, à ses normes et valeurs, et considère ce qui est situé en dehors de celle-ci l'Étranger - comme négatif ou tout juste bon à être annexé,

3. Cited in Newmark (1989), p. 7.

4. It could still be considered an ethnocentric translation if the primary readership is considered to be African. In that case, the content (or semantic interpretation) of the source text and the target text will be essentially African thought, and the European language of writing (the target language) will serve only as a medium for conveying African thought across ethnic linguistic boundaries in Africa. However, it is known that African writers produce their works with the intention of making them available to both African and non-African readers. 
adapté, pour accroître la richesse de cette culture" (p. 48). Ethnocentric translation gives priority to meaning over form (or style), paying particular attention to preserving the target language structure and norms.

The opposite of ethnocentric translation is traduction hypertextuelle, which Berman defines as "tout texte s'engendrant par imitation, parodie, pastiche, adaptation, plagiat, ou toute autre espèce de transformation formelle, à partir d'un autre texte déjà existant" (1985, p. 49). However, Berman points out that it is inappropriate to view translation either exclusively as "captation de sens" (traduction ethnocentrique) or "transformation littéraire" (traduction hypertextuelle) $(1985$, p. 58). To achieve a balanced translation of a literary work, meaning and form should be viewed as a whole. However, not every aspect of form is translatable. Every work of art has an untranslatable side to it which is a way of ensuring its "auto-affirmation" (1985, p. 60).

It is by coming to terms with what Berman refers to as "l'adhérence obstinée du sens à sa lettre" (1985, p. 59) that one can really appreciate the translation process adopted by some translators of African literature who, for the most part, have elected to translate African thought literally into European languages, since they understand the significance of the rapport between "sens" and "forme." As noted by Berman (1985, p. 36), "littéralité" is not necessarily "mot à mot," neither is it "calque." Literal translation, as practised by translators of African creative writing, is an example of what Berman means when he asserts that meaning and form are inseparable.

\section{Semantic versus communicative translation}

Peter Newmark (1981) also highlights the significance of literal translation when he discusses differences between semantic and communicative translation. Clearly, Newmark argues for the role of semantic translation when he says, "I am writing against the increasing assumption that all translation is (nothing but) communicating, where the less effort expected of the reader, the 
better" (1981, p. 51). Semantic translation attempts to recreate the tone and flavour and elegance of the original and in this process: "words are 'sacred,' not because they are more important than the content, but because form and content are one" (1981, p. 47). In Newmark's view, what really matters in translation is accuracy and objectivity, and on that score, semantic translation is more reliable than communicative translation. Hence, with this view in mind, Newmark points out that:

If the SL text is entirely bound up with the culture of the SL community - a novel or a historical piece or a description attempting to characterize a place or custom of local character - the translator has to decide whether or not the reader requires, or is entitled to, supplementary information and explanation. (1981, p. 21)

As an example, Newmark refers to the translation of Shakespeare's sonnet No. XVIII. He disagrees strongly with the view that "Shall I compare thee to a summer's day?" cannot be translated semantically in the language of a country where summer is unpleasant. As he sees it, the reader of a semantically translated version of the poem should be struck by the beauty of the English summer and become somewhat sensitized to the English culture. On the other hand, a communicative translation of the poem into a Middle-Eastern language, for example, will require another set of images and would thus result in an entirely different poem (1981, p. 50).

Newmark's example above provides the most valid explanation for the kind of translation process adopted by translators of African works, and states quite clearly why semantic (or literal) translation is given priority over communicative translation in expressing African thought in European languages. This view constitutes the main tenet of our approach to the translation of African literature.

\section{Preserving cultural homogeneity in translation}

The main aim of the translator of African works is to preserve the cultural homogeneity of African thought. His effort is 
generally geared towards transferring the source-language culture into the target-language culture with a minimal distortion of both languages and cultures. The culture-specificity of any literary work retains its validity for the peoples and regions to which the works belong. Contrary to the prevailing practice in literary translation, whereby contextual specifics of the sourcelanguage culture are often adapted to the target-language culture, translation of African works seeks to infuse the European language with African sociocultural specifics, thus appropriating the European language without much regard for its own culture. This is an important strategy in the Africanization of European language writing.

\section{A two-tier approach to intercultural translation}

Translating African creative works is a double "transposition" process: (1) primary level of translation, i.e. the expression of African thought in a European language by an African writer; (2) secondary level of translation, i.e. the "transfer" of African thought from one European language to another by the translator. The primary level of translation results in an African variety of the European language, and the translator's task is to deal with the unique problems posed by this so-called non-standard language. At this secondary translation level we are dealing not only with the interlingual but also the intersemiotic translation process, as both the content and formal characteristics of the African oral narrative are crucial to the full representation of meaning in the written target language. For the most part, the African content and form have already been captured by the African author in his European language of writing. It is the same African content and form that the translator has to carry across into the target language (European L2). Discussing Achebe's works, Ekundayo Simpson (1979) puts it this way: "Since the author has already bridged the gap between the Nigerian idiom and the European one, all the translator has to do is to find the equivalent expression and register in the foreign language" (p. 79). However, many other factors come into play to render the process a little more complicated than it seems. First, though somewhat homogenous, the English and French cultures do not always 
share the same world-view. This divergence in perception often results in linguistic and cultural differences between the two language groups, which will thus add to the difficulty of "transferring" African thought from one European language into another. The interrelationship between language and culture makes it difficult to envisage how a language can cope with the demand that it shake off its own culture (so to speak) to serve as a medium for conveying another remote or alien culture. Secondly, the situation is further complicated as even the source text itself involves two cultures - the culture of the European language of writing and the African culture being transmitted. The coming together of the two results in a source text of a hybrid nature, which is bound to pose specific translation problems. Thirdly, there is a subjective dimension to the process, which is that the translator's own "life-world" and experience can have a serious impact on the translation. According to Gadamer (1975), an understanding cannot be achieved that is completely free of the interpreter's own "life-world." The interpreter, or translator, is a "victim" of his own concrete hermeneutic situation, and all interpretative understanding is necessarily bound to preconceptions and prejudgments. Only by further penetrating the material of an alien language with an openness for cultural differences can the interpreter's preconceptions derived from his own cultural background show themselves to be arbitrary.

At this level of translation, the translator should strive to operate at the level of the author, thus assuming that both translator and target audience receive the text at the author's level within his culture (Newmark, 1989). It is advantageous, therefore, for the translator to share a similar "life-world" with the author. For instance, if $s /$ he is African s/he will be more familiar with the cultural background of the narrative to be translated. D'Almeida shares this opinion as seen in the following statement:

When it is an African person who is translating an African writer, impersonation is somewhat easier and more effective because the African person is more familiar with the cultural background in which the actions occur and in which the characters are set. Religious rituals, festivals, customs and even 
day-to-day occurrences are seen from within because they are part of a shared experience. (1981, p. 25)

However, there is no guarantee that the job will be easier as the African translator may bring along his own perception of the oral tradition reality, and as he will also have to deal with the problems of expressing ideas he understands best in his native tongue in his second language. It is generally believed in the practice of translation that a native speaker of the language into which a translation is being carried out is best qualified for the task. In other words, the general tendency is for one to translate into one's own mother-tongue. However, at this level of translation, interpretation and understanding take precedence over everything else. Emphasis here should be placed on the interpretative ability of the translator and not just on his communicative skills, as understanding is a necessary prelude to communication. The European languages used in African writing have been so localized that, as stated by Simpson (1980):

much may be lost to the uninitiated European translator whose only title to competence is that he is working into his own mother-tongue. [...] there are terms used or created by Englishspeaking Africans which their French-speaking counterparts would express better in French than the mother-tongue French speaker of the colonial metropolis, and vice-versa. (pp. 14-18)

Hence, at this translation level, the "ideal" translator is one who is less likely to "activate scenes that diverge from the author's intentions or deviate from those activated by a native speaker of the source language (a frequent cause of translation error)" (SnellHornby, 1988, p. 81).

The result of the translation at this level can be described as being thrice removed from reality, since it is the final product of an interpretation process which goes from the African oral tradition to the author's European language of writing and finally to a second European language. 


\section{Some translation techniques: Translation shifts}

The translation techniques used by African writers and translators of African works to express African thought in European languages can be summed up under the heading "translation shifts." Translation shifts, as used in African writing, is a ready solution for what Catford (1965) refers to as cultural untranslatability. The latter, as opposed to linguistic untranslatability, occurs when a situational feature which is functionally relevant for the source language text is completely absent from the culture of the target language (Catford, 1965, p. 99). Shifts here would include calques, semantic shifts and collocational shifts.

\section{A. Calques}

By calques we mean the almost literal translation of native words and expressions into European languages. Calques can also include whole sentences or native expressions that are usually considered to be sayings or idiomatic expressions in the native language. Such calques are language specific utterances that are translated into the European language, and which can only be understood in terms of the sociocultural background of the linguistic community in which they are used. Below are some examples and their respective translations:

(1) "Moon, may your face meeting mine bring good fortune"(Achebe, 1964, p. 2)

"Lune, puisses-tu me voir et m'apporter le bonheur" (d'Almeida et al., 1978, p. 12)

(2) "This my friend" (i.e. this friend of mine) (Achebe, 1964, p. 96)

"Celui-ci, de mon ami" (d'Almeida et al., 1978, p. 131)

"May we live to see tomorrow" (i.e. goodnight) (Okara, 1964, p. 51)

"Puissions-nous voir le jour qui va suivre" (Sevry, 1985, p. 43)

"long throats" (Achebe, 1964, p. 121)

"les gens cupides" (d'Almeida et al., 1978, p. 162) 
(6) "speak into my words" (Achebe, 1964, p. 144)

"mêler tes mots aux miens" (d'Almeida et al., 1978, p. 193)

(7) "to be found at home" (Achebe, 1964, p. 122)

"trouver 'à la maison'" (d'Almeida et al., 1978, p. 165)

\begin{abstract}
"at the end of the carefree season between harvest and planting" (Achebe, 1958, pp. 20-21)

"à la fin de la saison sans souci qui s'étend entre la récolte et les semailles" (Ligny, 1966, p. 40)
\end{abstract}

The statement in (1) is a way of speaking among many African traditional peoples. It falls within a certain register of expressions used in prayers, incantations, religious or ritualistic ceremonies. The "shining" of the moon is referred to as the "face of the moon." The appearance of the new moon is highly symbolic in traditional Africa and is closely linked to the activities and beliefs of the people. As it often happens at the beginning of each month, the speaker, searching for a new moon in the sky may be hampered by dark clouds, for instance. Hence, a flicker of light from the new moon falling on the speaker's face is described as "the face of the moon meeting the face of the speaker," and this is believed to bring good fortune to the speaker. The translation of "may your face meeting mine" as "puisses-tu me voir" deviates from the native idiom, yet, it still conveys the mystic or ritualistic character of the statement.

"This my friend" in (2), which is commonly used in West African English and pidgin, is another calque from the West African vernaculars. It shows how the demonstrative is used together with a possessive adjective to convey a sense of intimacy, familiarity, closeness or endearment in African languages. It simply means "this friend of mine" which is what one would be inclined to say in standard European English. The translation "Celui-ci, de mon ami" shows that the translators may have been aware of the sociocultural value of the expression; however, it does not adequately convey the same meaning as the original. In fact, it is an awkward expression in French which 
might have been acceptable if it had captured the sociocultural essence of the original expression.

The ljaw people of Nigeria bid each other goodnight by saying "May we live to see tomorrow" (3). The statement comes from a time when travelling at night was dangerous as wild animals roamed about in the villages. It often happened that people would bid each other goodnight and wake up the next morning to learn that their companion of the night before had been killed by a wild animal. Thus, this kind of expression carries with it a great deal of sociocultural history which the translator must take seriously. Sevry's translation, "puissionsnous voir le jour qui va suivre," though somewhat wordy, is a reasonably adequate translation of the expression.

In some African languages, as well as in West African pidgin English, the expression "long throat" (4) is used to refer to a greedy person. There is a certain local image attached to it, which seems to have been lost in the standard French translation "les gens cupides."

"They are quiet" in (5), a native way of saying "my people (family) are well," is well rendered as "Ils sont sages" to retain the humour. "Speak into my words" (6) is beautifully rendered as "mêler tes mots aux miens."

"To be found at home" in (7) (i.e. to be married a virgin) translated as "trouver 'a la maison" misses the point completely. This may explain why "à la maison" is put between quotation marks; it is an indication of the difficulty the translators might have had in finding a French equivalent for the native expression.

In characteristic fashion, Achebe provides some information about the meaning of "carefree season" in (8) by informing the reader that it is the period between harvest and

5. For example, the image of some greedy person stretching his or her neck to see if there is still food in the cooking pot. 
planting. Obiechina (1975) provides additional information when he describes the season as "the season of rest from labour, the season of festivities and of peace" (p. 125). It was the season when people did the "lighter task of the after-harvest season" (p. 125). Hence, the predominant factor here is the idea of relaxation, peace and celebrations. Ligny's translation of "carefree season" as "saison sans souci" is, for lack of a better rendition, acceptable; however, it still leaves something to be desired. It expresses the idea that during this season people try to forget about their problems or worries, but it fails to convey the idea that it was a season of festivities and the celebration of traditional values. To capture its full meaning, the expression could be translated as: "saison de repos et de fêtes."

The English and French languages cope with the difficulty of capturing the full scope of meaning of the African idiom with varying degrees of success. This difference in the potential of both languages in dealing with the culture-specific elements of the African oral narrative has also been discussed by d'Almeida (1980) who has first-hand experience with translating the African novel between both languages.

\section{B. Semantic shift}

Semantic shift is another translation technique commonly used in African literature to secure the African world-view in Europeanlanguage works. A semantic shift occurs when known lexical items in the target language are assigned features of meaning from the source language such that the derived meaning preserves the African content of the source text, even though the new meaning is not native to the target language. The following are examples whereby a European word is assigned a new meaning that can only be understood within the context in which it is used.

(1) "How is it (moon) sitting? [...] its (moon) legs were up in the air" (Achebe, 1964, p. 2)

"Comment s'est-elle placée? [...] ses 'pointes' étaient en l'air" (d'Almeida et al., 1978, p. 13) 
(2) "to whisper together like in-law and in-law" (Achebe, 1964, p. 61)

"pour vous chuchoter quelque chose dans l'oreille, comme cela se fait entre beaux-parents" (d'Almeida et al., 1978, p. 86)

(3) "Her own badness whistles" (Achebe, 1964, p. 67)

"Son mauvais caractère crève l'ceil" (d'Almeida et al., 1978, p. 95)

(4) "Who gets money reach him" (Okara, 1964, p. 118)

"Qui peut avec de l'argent l'atteindre?" (Sevry, 1985, p. 115).

The use of "legs" in (1) is unusual in the English language. That is, "moon" and "legs" do not normally collocate in this manner within the English sentence. In other words, it is unusual to talk of the "legs of the moon" in the English worldview. Achebe has merely translated literally from his native tongue, in which the two pointed, or sharp, ends of the crescentshaped new moon are referred to as "legs." The translators put the word "pointes" between quotation marks probably to indicate that they were aware of the culture specificity of the use of the word "legs" but could not find a better rendition in French. The translation of "sitting" by "placée," instead of "assise," also constitutes some loss in the traditional discourse as used by Achebe.

The expression in (2) "to whisper together like in-law and in-law" is so charged with sociocultural implications that an African conversant with his oral tradition will immediately perceive its significance in the passage. The expression implies much more than a simple idea of conversation, discussion, chat, and so on. It connotes the secrecy, rituals and solemnity involved in marriage negotiations in traditional Africa. In fact, being Africans themselves, the translators were extremely conscious of the sociocultural import of the expression and that may explain why they came up with what appears to be an over-translation. It may also be a deliberate attempt to make the information available to readers without the required sociocultural knowledge. Expressions like "chuchoter quelque chose dans l'oreille" and "comme cela se fait entre beaux-parents" sound more like explanations of the idea of "whispering together" rather 
than direct translations. The original meaning is not lost; the sociocultural value of the expression is maintained somewhat, yet one has the feeling that some parts of the translation (e.g. "quelque chose dans l'oreille") are mere additions to the idea of "chuchoter."

In (3) the use of the word "whistles" is non-English. It is a literal translation from the Ibo language and thus carries with it a certain world-view ${ }^{6}$. The translators opt for an expression that can be more easily understood by the non-African reader ("Son mauvais caractère crève l'œil"), which of course, has an equivalent meaning, but unfortunately does not convey the Ibo world-view. The word "whistle" in English also means "advertise." However, it is not the main idea implied in the Ibo expression. The expression simply means that the character is notoriously wicked. The translators chose a French expression, "crève l'œil," which conveys the meaning of "advertise" but loses out on the local colour and cultural meaning contained in this West African use of the word "whistle."

The use of the word "reach" in (4) is reminiscent of its use in pidgin. However, it is also a literal translation from the Ijaw language. It is rather unfortunate that the translator was unaware of this use of "reach" in West African English, which led him to commit a "faux sens." The original, "Who gets money reach him?", means "Who has as much money as he?" or "Nobody is as rich as he." But the translation, "Qui peut avec de l'argent l'atteindre?" renders the standard use of "reach" in English, meaning "Can anyone reach him with money?" The translation, therefore, might convey the impression that it is difficult to get the attention of the individual in question with money, which is the exact opposite of what the original statement is meant to convey. Viewed against the background of the entire novel, the

6. The expression also exists in some West African languages. For example, in Bamileke, a semi-bantu language from the Cameroon Grassfield group, the statement will translate into something like: "Her bad-heart (wickedness) whistles." 
individual in question is a rich man who made his fortune through bribery and corruption. Indeed, you can only get his attention by using money as a bait, that is, by offering him a bribe. The statement would translate into French as: "Qui est aussi riche que lui?" If the West African use of "reach" is to be taken into account, the translation would be something like: " Qui peut avec de l'argent atteindre son niveau (ou son rang)?" These types of semantic shift are technically different from calques, although they are literal translations from native African languages. What is interesting here is the way new meaning is assigned to known European words or groups of words.

\section{Collocational shift}

Another form of translation shift practised by translators of African works is collocational shift. Sometimes, in order to convey African meaning, the African author combines words in his European language of writing without regard for collocational rules such as selectional restrictions or co-occurrence. In cases where the collocated forms do not violate the rules, the African author may assign a new meaning to the forms, thus altering their likely co-occurrence in native use. The violation of collocational rules accounts for the non-nativeness of the collocated sequences and, therefore, their Africanness. Collocational shift also occurs when the African writer turns around the syntax of the European language in order to reflect the syntax of his native language. Sometimes, compounds are formed following the pattern in which compounding takes place in the European language although the resulting compound is not native to the European language. The compounds are used either as summaries of longer expressions from the native language or, to express meaning represented by only one word in the native language. The following are a few examples:

\section{a. Names, references and modes of address}

The translation of names, references and modes of address presents specific challenges as their occurrences in the European language are often the result of the author's attempt to capture 
them as they exist in African languages. African praise names, for instance, pose specific problems as they are often expressed in elaborate compound formations that may not have the same form in English and French. For example, in Achebe's Arrow of God (1964), a young man teases his sister about her runny nose by calling her "Never-a-dry-season-in-the-nose" (p. 210). Achebe decides to create a compound expression out of this idea which is expressed in accordance with the tendency for African names to have meaning. D'Almeida et al. (1978) translate it as: "Regardez son nez qui n'a jamais connu de saison sèche!" (p. 276). Obviously, the translation takes neither the form of a praise name nor that of a nickname. The oral tradition flavour that Achebe had intentionally sought to preserve by using a compound structure has been lost in this rather loose comment in French about the girl's nose. A similar explanation would hold true for the translation of "Anthill nose" (Achebe, 1964, p. 210) as "Et ton nez à toi? Il ressemble à une termitière" (d'Almeida et al., 1978, p. 276). It is surprising that the translators did not think of something as straightforward as "Nez-de-termitiere," which would have been much closer to the one-word expression and would have maintained its form as a nickname and, consequently, its oral narrative quality. However, a notable exception is Green's translation of "Abraham le Désossé" (Beti, 1957, p. 52) as "Abraham the Boneless Wonder" (Green, 1958, p. 32) which is generally very adequate, as it maintains the praisename (nickname) structure of the original and brings out the humour implied in the name by the use of the word "Wonder." D'Almeida et al. also translate the references "Yesterday's body" (Achebe, 1964, p. 123), and "Yesterday's wood ash" (Achebe, 1964, p. 123) as "sans un corps nouveau" (1978, p. 166) and "les cendres de la veille" (1978, p. 168) respectively. Of the two translations, "les cendres de la veille" sounds more like a reference. Since "yesterday's" is a modifier in both references in the original, one would imagine that the translators would have rendered "Yesterday's body" as "le corps de la veille" in much the same way as they had rendered "Yesterday's wood ash" as "les cendres de la veille." At least, this would have given the expression the characteristic of a reference in much the same way as it occurs in the oral narrative. In the translation of these names and 
references, their oral narrative characteristics are just as important as the meaning conveyed by the names. The translator should therefore endeavour to reproduce the oral poetry in the names which, after all, constitutes the significance of their use in the creative works of the authors. Michel Ligny (1966) is quite aware of this fact when he translates the praise names "Dry-meat-thatfills-the-mouth" (Achebe, 1958, p. 66) as "Viande-sèche-quiemplit-la-bouche" (p. 114); and "Fire-that-burns-without-faggots" (Achebe, 1958, p. 66) as "Feu-qui-brûle-sans-fagots" (p. 114).

\section{b. Kinship terms}

Kinship terms also present cultural characteristics that should be preserved in the translation, as they are used deliberately by the African writer to enhance the local colour of his works. Although the occurrences of these kinship terms do not violate the syntactic rules of the European languages, they are nonetheless unusual from a pragmatic point of view. D'Almeida et al. (1978) translate Achebe's (1964) "Son of our daughter" (p. 23) as "Fils de notre fille" (p. 37); "Father of my mother" (p. 23) as "Père de ma Mère" (p. 38); "Mother of my husband" (1964, p. 73) as "Mère de mon Mari" (p. 102). Okara's (1964) direct translation from Ijaw, "Your father's father's father" (p. 95), is translated as "Père du père de ton père" (Sevry, 1985, p. 91); "the son of the son of the son of Bumo" (p. 96) is translated as "le fils du fils du fils de Bumo" (Sevry, 1985, p. 92). The translator of Camara Laye's Enfant noir indicated his awareness of the importance of kinship terms by translating the statement "Etes-vous mon oncle Mamadou?" (Laye, 1954, p. 169) as "Are you my father's brother, Mamadou?" (Kirkup, 1959, p. 122), thus improving somewhat on the author's version.

\section{c. Violated syntax}

In translating Okara's The Voice, Sevry had to deal with Okara's frequent syntactic jugglery in statements such as, "Who are you

7. Instead of "Are you my uncle, Mamadou?" 
people be?" (1964, p. 26) translated as "Et vous, les gens, qui pouvez-vous être?" (1985, p. 15); "If you are coming-in people be, then come in" (1964, p. 27) translated as "Si vous devez être des gens à entrer, alors entrez" (1985, p. 15); "You cannot a thing I have done not put on my head; How can you on my head put a thing that happened not?" (1964, p. 66) translated as "Vous ne pouvez pas une chose qui point $n^{\prime}$ ai accomplie me faire endosser; Comment pouvez-vous me faire endosser une chose qui point ne s'est passée?" (1985, p. 60)

One can only commend Sevry for successfully dealing with the translation problems posed by these vernacular-based expressions, even though, for some reason, the French renditions do not often seem to capture the native expressions as well as the English language does. This disparity may be due to the fact that the English version is written by the African author "translating" almost literally from his vernacular, while the French version is a translation of the author's text made by a Frenchman who may not have the same sensibilities as the author vis-a-vis the Ijaw language and culture. A close examination of the translations would, however, reveal a measure of ingenuity by Sevry. He "bends" the French language in an attempt to reproduce Okara's unusual syntax, and, being somewhat dependent upon the genius of the French language, resorts to the use of archaic negative structures such as "que point n'ai accomplie," "qui point ne s'est passée," to compensate for the lack of a similar syntactic play in French. The noun phrase "coming-in people be" has been translated by something equally bizarre, "des gens à entrer." The expression "put on my head" meaning: put the blame on me, or hold me responsible, (or in standard English: to be on my head) is a literal translation of an expression that exists in some West African languages. Indeed, the expression is also well-known in West African Pidgin English as "put trouble for my head." Sevry, however, chooses to translate the expression by its idiomatic equivalent in French "me faire endosser." There is, therefore, a form of transposition regarding the metaphorical use of body parts, from "head" in English to "dos" in French, which translates into "shoulder" in English as in the expression "to shoulder 
responsibility for." There is a slight loss in the sociocultural significance of the expression in Sevry's translation.

Translation shifts are therefore a technique used by African writers to express in their adopted European language the semantic and stylistic characteristics of their native tongue. Translators of African works often strive to cope with this technique in an attempt to retain the African content of the works.

\section{Conclusion}

The above analyses point to the fact that African writers and translators of African works have a clear preference for semantic, overt or literal translation. As indicated earlier, the "transposition" of African thought into European languages is a carry-over of African sociolinguistic and sociocultural values into the European language. The modification of the host European language results in an African variety of the language, which should be considered a "standard" variety in its own right if any successful translation is to be operated upon it.

Hence, translating African creative works is a source-text oriented translation process in which the target language, the European language, is modified to accomodate the African world-view. This process goes far beyond merely substituting linguistic and cultural equivalents. It is a negotiating process in the sense that two divergent sociocultural systems that are in contact attempt to arrive at a happy solution in expressing the African world-view in the European language. This negotiating process is made possible through translation techniques such as calques, semantic and collocational shifts ${ }^{8}$.

Concordia University

8. There are many more mechanisms used by translators of African creative writing to cope with the difficulties of translating this kind of literature. A more complete account can be found in Bandia (1993). 


\section{References}

A. African literary works cited

ACHEBE, C. (1958). Things Fall Apart. London, Heinemann.

(1966). Le Monde s'effondre. Trans. by M. Ligny. Paris, Présence Africaine.

(1964). Arrow of God. London, Heinemann.

(1978). La Flèche de Dieu. Trans. by I. A. d'Almeida and

O. M. L. Simpson. Paris, Présence Africaine.

BETI, M. (1957). Mission terminée. Paris, Éditions Buchet/Chastel.

(1958). Mission to Kala. Trans. by P. Green. London, Heinemann.

LAYE, C. (1954). L'Enfant noir. Paris, Librairie Plon.

(1959). The African Child. Trans. by J. Kirkup. Glasgow, William Collins Sons \& Co.

OKARA, G. (1964). The Voice. London, Heinemann.

(1985). La Voix. Trans. by J. Sevry. Paris, Hatier.

B. Secondary references

BANDIA, P. (1993). Sociolinguistic and Sociocultural Aspects of Translation: A Cross-Cultural Study in an African Context. Ph.D. Dissertation. Université de Montréal.

BERMAN, A. (1985). Les Tours de Babel: essais sur la traduction. Mauvezin, Trans-Europ Repress. 
CATFORD, J. C. (1965). A Linguistic Theory of Translation. Oxford, Oxford University Press.

CHINWEIZU, J. Onwuchekwa and M. Ihechukwu (1980). Toward the Decolonization of African Literature: African Fiction and Poetry and their Critics. London, Routledge.

D'ALMEIDA, I. A. (1981). "Literary translation: the experience of translating Chinua Achebe's Arrow of God into French." Babel, XXVII (1), pp. 24-28.

GADAMER, H.-G. (1975). Truth and Method. Trans. and ed. by G. Barden and J. Cumming. New York, Seabury Press.

GÉRARD, A. S., ed. (1986). European-Language Writing in SubSaharan Africa, vol. I and II. Budapest, Akadémiai Kiado.

HOUSE, J. (1977). A Model for Translation Quality Assessment. Tübingen, Gunter Narr Verlag.

NEWMARK, P. (1981). Approaches to Translation. Oxford, Pergamon Press.

(1989). "Modern Translation Theory." Lebende Sprachen,

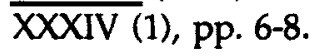

OBIECHINA, E. N. (1975). Culture, Tradition and Society in the West African Novel. Cambridge, England, Cambridge University Press.

SIMPSON, E. (1979). "Translation from and into Nigerian languages." Babel, XXV (2), pp. 75-80.

(1980). "Translation and the socio-cultural problems of developing countries." Babel, XXVI (1), pp. 14-18.

SNELL-HORNBY, M. (1988). Translation Studies: An Integrated Approach. Amsterdam/Philadelphia, John Benjamins. 
ABSTRACT: Translation as Culture Transfer: Evidence from African Creative Writing - Due to the impact of African oral tradition the language of African creative writing in European languages (French and English) poses specific translation problems. We wish to illustrate the various processes and techniques used to cope with these translation problems. The different translation techniques discussed will throw some light on well-known concepts in translation theory such as Newmark's semantic vs communicative translation, House's overt vs covert translation, Diller and Kornelius' primary vs secondary translation and Berman's "traduction ethnocentrique" vs "traduction hypertextuelle." Translation as culture transfer, particularly regarding non-related language cultures, has been discussed by translation theorists such as Mounin, Nida, Lefevere, and Snell-Hornby. Translating African creative works is a double "transposition" process: (1) primary level of translation i.e., the expression of African thought in a European language by an African writer; (2) the "transfer" of African thought from one European language to another by the translator. The primary level of translation results in an African variety of European languages, and the translator's task is to deal with the unique problems posed by this so-called non-standard language. This paper is focussed on the various translation techniques used by translators of African works. These translators show a clear preference for semantic, overt and "literal" translation, in which, in Nida's terms, formal equivalence is given priority over dynamic equivalence. Such an approach is judged by the translators to be the most reliable for an effective representation of African sociocultural and sociolinguistic reality in European languages.

RÉSUMÉ: Traduction et transfert culturel: le cas de la création littéraire africaine - La tradition orale africaine exerce une influence marquée sur le langage de la création littéraire africaine en langues européennes (le français et l'anglais) qui pose des problèmes de traduction particuliers. La présente étude décrit les diverses techniques et les divers procédés de traduction utilisés par les traducteurs d'œuvres africaines écrites en langues européennes. La discussion de ces procédés conduit à aborder des concepts bien connus dans le domaine de la traductologie: la traduction sémantique et la traduction communicative de Newmark, la "overt translation» et la "covert translation» de House, la traduction primaire et la traduction secondaire de Diller et Kornelius et enfin la traduction ethnocentrique et la traduction hypertextuelle de Berman. La traduction comme transfert culturel, particulièrement en ce qui concerne des langues de cultures très éloignées l'une de l'autre, a été abordée entre autres par des théoriciens tels que Mounin, Nida et Snell-Hornby. 
La traduction d'œuvres africaines est une "double transposition»: (1) l'auteur exprime la "pensée» africaine en langue européenne; (2) le traducteur effectue un "transfert» de la pensée africaine d'une langue européenne à une autre. La variété africaine de la langue européenne constitue un défi pour le traducteur, qui doit surmonter les problèmes particuliers que pose la traduction d'une telle variété «non standard» de langue européenne. Une analyse des divers procédés utilisés par les traducteurs d'œuvres africaines en langues européennes révèle une préférence marquée pour une traduction plutôt sémantique, transparente («overt») et littérale, dans laquelle, pour emprunter à E. Nida, l'équivalence formelle l'emporterait sur l'équivalence dynamique. Cette approche est la plus apte, selon les traducteurs, à assurer une représentation efficace des réalités sociolinguistiques et socioculturelles africaines en langues européennes. 